DOI: http://dx.doi.org/10.1590/1678-457X.6243

\title{
Bioactive and volatile organic compounds in Southern Brazilian blackberry (Rubus fruticosus) fruit cv. Tupy \\ Andressa Carolina JACQUES ${ }^{1,2 *}$, Fábio Clasen CHAVES ${ }^{1}$, Rui Carlos ZAMBIAZI ${ }^{1}$, Márcia Campos BRASIL ${ }^{3}$, Elina Bastos CARAMÃO ${ }^{3}$
}

\begin{abstract}
Blackberry (Rubus fruticosus, cultivar Tupy), an expanding fruit crop in southern Brazil, is greatly appreciated for its flavor and bioactive potential with limited characterization of its metabolite content. The purpose of this study was to characterize the bioactive and volatile organic compound (VOC) content of mature blackberry fruit of cultivar Tupy. Gallic acid, (-)-epicatechin, ferulic acid, and quercetin were the main phenolic compounds found in mature fruit. Among the VOCs identified in 'Tupy' blackberry were important flavor components characteristic of fruit berries, including hydrocarbons, alcohols, aldehydes, ketones, esters, and terpenoids. Some of the VOCs had not been previously found in blackberry, while others have been associated with typical blackberry flavor.
\end{abstract}

Keywords: flavor; phenolic compounds; blackberry.

\section{Introduction}

Blackberry (Rubus spp) was introduced to Southern Brazil in the 1970s and has adapted well to the temperate climate of the region with high productivity (up to $10,000 \mathrm{~kg} / \mathrm{ha} /$ year) and low costs of implementation and management (Antunes, 2002; Finn, 2008). The Embrapa Pelotas (RS, Brazil) breeding program has released several blackberry cultivars including the high quality cultivar 'Tupy', which is also currently cultivated in Mexico and exported to the United States. 'Tupy' is a cross between cv. Comanche and an unknown clone called 'Uruguay' originating from that country (Antunes, 2002; Finn, 2008).

Blackberry fruit can be consumed fresh or processed as jam, cake, marmalade, ice-cream, frozen, dried, juice, wine, and liqueur (Antunes, 2002; Finn, 2008). Product acceptance is dependent on fruit flavor, which is composed of volatile compounds, and also on the balance between acids and sugars. Fruit metabolism during ripening, postharvest handling, and storage are determinants for flavor volatile production and also dependent on factors such as maturation stage and plant species (Christensen et al., 2007; Riu-Aumatell et al., 2004). Several methods are available for aroma analysis including solvent extraction and techniques for pre-concentrating volatiles such as solid-phase micro extraction (SPME) (Riu-Aumatell et al., 2004). Although many studies have analyzed volatiles from different Rubus species (Kallio \& Linko, 1973; Malowicki et al., 2008; Meret et al., 2011; Pyysalo, 1976), and from different blackberry cultivars (Du et al., 2010; Georgilopoulos \& Gallois, 1987; Klesk \& Qian, 2003), no one has studied the volatiles produced by Brazilian blackberry fruit cv. Tupy.

The contribution of fruit consumption to human health goes beyond supplying essential nutrients for nourishment to include a diverse array of bioactive secondary metabolites from fruit extracts such as phenolic compounds, tocopherols, and ascorbic acid that have been implicated in the prevention of cardiovascular diseases and cancers (Seeram et al., 2006).

As part of an effort to increase consumer acceptance through the increased knowledge of quality attributes and as a support to breeders for improvement of fruit quality of this expanding fruit crop, this study reports the main bioactive and volatile compounds identified in 'Tupy' blackberry.

\section{Materials and methods}

\subsection{Materials}

Blackberry (Rubus fruticosus) fruits of cultivar Tupy were handpicked on the same day at 9 AM at maturity stage from a local grower in Morro Redondo RS, Brazil, and stored at -80 ${ }^{\circ} \mathrm{C}$ for further analyses. At harvest, fruit had $11.2^{\circ}$ brix and titratable acidity of $0.97 \%$ of malic acid equivalents. Mature fruit from 10 'Tupy' clones were pooled and then separated into three biological replicates. For each analysis, the appropriate amount (described below) of sample from each replicate was used.

SPME (Supelco, Bellefonte, PA, USA) DVB/CAR/PDMS $50 / 30$ fibers were used for sample volatile collection. The fibers were conditioned prior to use according to supplier's instructions.

All chemicals were GC or HPLC grade and purchased either from Sigma (Saint Louis, MO, USA) or Fluka (Milwaukee, WI, USA), except for $\beta$-cryptoxanthin, lycopene, lutein, and zeaxanthin, which were purchased from Chromadex (Irvine, CA, USA). 


\subsection{HPLC analyses of bioactive compounds}

All bioactive compound analyses were performed using a Shimadzu HPLC, with FL and UV detectors, a CLC-GODS guard column, and a Shimadzu RP-18 CLC-ODS ( $5 \mu \mathrm{m} \times$ $4.6 \mathrm{~mm} \times 150 \mathrm{~mm}$ ) column at $25^{\circ} \mathrm{C}$.

\section{Phenolic compounds}

Briefly, $5 \mathrm{~g}$ of sample were ground in liquid nitrogen, dissolved in methanol $(30 \mathrm{~mL})$, and acidified with $\mathrm{HCl}(1.2 \mathrm{M})$ (Hakkinen et al., 1998). The extract was incubated in a water bath at $35^{\circ} \mathrm{C}$ in the dark for $24 \mathrm{~h}$. The mixture was filtered and concentrated to dryness. The residue was redissolved in methanol $(5 \mathrm{~mL})$, centrifuged at 7,000 rpm for $10 \mathrm{~min}$, and $30 \mu \mathrm{L}$ of the supernatant was injected in the HPLC system. HPLC gradient separation used mobile phase A (water:acetic acid, 99:1) and B (methanol), at a flow rate of $0.8 \mathrm{~mL} \mathrm{~min}^{-1}$. The gradient started at 100\% A and linearly changed to $60 \% \mathrm{~A}$ and $40 \% \mathrm{~B}$ at $25 \mathrm{~min}$, then at $37 \mathrm{~min}$ to $95 \% \mathrm{~A}$ and $5 \% \mathrm{~B}$ until $42 \mathrm{~min}$, and back to the initial conditions after $3 \mathrm{~min}$. The UV detector was set at $280 \mathrm{~nm}$. Total run time was $45 \mathrm{~min}$.

Compound identification was based on retention time comparison to the following standards: caffeic acid, ferulic acid, gallic acid, $p$-hydroxybenzoic acid, quercetin, and (-)-epicatechin. Quantification was based on an external standard calibration curve.

\section{Carotenoids}

The sample ( $5 \mathrm{~g}$ ) was ground with $2 \mathrm{~g}$ of celite; cold acetone was then added, and the mixture was stirred for $10 \mathrm{~min}$. (Rodrigues-Amaya, 2001). The sample was filtered under vacuum, and acetone was used to wash the material until the filtrate passing through the funnel became clear. The extract was partitioned using $30 \mathrm{~mL}$ of petroleum ether and $100 \mathrm{~mL}$ of distilled water. The organic phase was washed three more times and then transferred to a volumetric flask, and the volume was brought to $50 \mathrm{~mL}$ with petroleum ether. $25 \mathrm{~mL}$ of the sample solution were saponified using potassium hydroxide $(1.5 \mathrm{~N}$ in ethanol) in the dark for $18 \mathrm{~h}$. Upon phase separation, the extract was concentrated to residue and resuspended in the HPLC initial mobile phase (methanol:acetonitrile, 30:70 v/v). The extract was centrifuged at 9,000 rpm for $6 \mathrm{~min}$, and a $25 \mu \mathrm{L}$ aliquot was injected in the HPLC.

HPLC gradient separation used mobile phase (A - methanol, $\mathrm{B}$ - acetonitrile, and C - ethyl acetate) at a flow rate of $0.9 \mathrm{~mL}$ $\mathrm{min}^{-1}$. The gradient started at $30 \% \mathrm{~A}$ and $70 \% \mathrm{~B}$ and linearly changed to $10 \% \mathrm{~A}, 80 \% \mathrm{~B}$, and $10 \% \mathrm{C}$ at $10 \mathrm{~min}$; then at $35 \mathrm{~min}$ the solvent ratio was $5 \% \mathrm{~A}, 80 \% \mathrm{~B}$, and $15 \% \mathrm{C}$ until $40 \mathrm{~min}$ and back to initial conditions after $2 \mathrm{~min}$. Total run time was $42 \mathrm{~min}$. The UV detector was set at $450 \mathrm{~nm}$. Compound identification was based on retention time comparison to the following standards: $\beta$-cryptoxanthin, lycopene, lutein and zeaxanthin, and $\beta$-carotene. Quantification was based on external standard calibration curves.

\section{Tocopherols}

Tocopherol extraction was performed according to the method described earlier for carotenoids (RodriguesAmaya, 2001). HPLC gradient separation used methanol (A), acetonitrile (B), and isopropanol (C) at a flow rate of $1 \mathrm{~mL} \mathrm{~min}^{-1}$. Gradient started at $40 \% \mathrm{~A}, 50 \% \mathrm{~B}$, and $10 \% \mathrm{C}$, and it was linearly changed to $65 \% \mathrm{~A}, 30 \% \mathrm{~B}$, and $5 \% \mathrm{C}$ at $10 \mathrm{~min}$; it was maintained for $2 \mathrm{~min}$, and then back to the initial conditions for a total run time of $15 \mathrm{~min}$. Fluorescence detector was set at an excitation wavelength of $290 \mathrm{~nm}$ and emission $330 \mathrm{~nm}$. Compound identification was based on retention time comparison with $\alpha$-, $\delta$ - and $\gamma$-tocopherol standards, and quantification was based on an external calibration curve.

\section{L-Ascorbic acid}

HPLC gradient separation used mobile phase A (water:acetic acid, 99.9:0.1) and B (methanol) at a flow rate of $0.8 \mathrm{~mL} \mathrm{~min}^{-1}$. The gradient started at $100 \% \mathrm{~A}$, at $5 \mathrm{~min}$ it was reduced to $98 \%$ $\mathrm{A}$ and $2 \% \mathrm{~B}$, held for $2 \mathrm{~min}$, then back to initial conditions for a total run time of $10 \mathrm{~min}$. The UV detector was set at $254 \mathrm{~nm}$ (Ayhan et al., 2001). Compound identification was based on retention time comparison to an L-ascorbic acid standard, and quantification was based on an external calibration curve.

\subsection{CG-MS analysis of volatile compounds}

Chromatographic analyses of volatile compounds were performed with a Shimadzu GCMS-QP5050 equipped with a OV5 column (Ohio Valley Specialty Chemical, USA), (30 m $\times 0.25 \mathrm{~mm} \times 0.25 \mu \mathrm{m})$, using helium as carrier gas $(99.99 \%$ pure, White Martins, Brazil) at a flow rate of $1 \mathrm{~mL} / \mathrm{min}$; and the injection split was set at 1:10. Temperature programming was as follows: oven temperature started at $60^{\circ} \mathrm{C}$ and then ramped up $5{ }^{\circ} \mathrm{C} / \mathrm{min}$ until $250^{\circ} \mathrm{C}$. Both injector and detector were set at $250{ }^{\circ} \mathrm{C}$. Mass spectra were obtained in the range of $40 \mathrm{~m} / \mathrm{z}$ to $400 \mathrm{~m} / \mathrm{z}$, scan speed 20 scans $/ \mathrm{s}$ and $70 \mathrm{eV}$. Compound identification was based on the compounds' unique fragmentation pattern confirmed by comparisons to the NIST05 library.

\section{Headspace SPME}

Fresh fruit $(3 \mathrm{~g})$ were ground and placed in a $15 \mathrm{~mL}$ vial with $3 \mathrm{~mL}$ water and $1 \mathrm{~g}$ of sodium chloride (added to increase extraction recovery). The vial was heated to $60^{\circ} \mathrm{C}$ for $15 \mathrm{~min}$, and the SPME fiber was exposed to the headspace for $30 \mathrm{~min}$. Sample injection was performed placing the SPME fiber in the heated chromatograph injection port for $5 \mathrm{~min}$.

\section{Solvent extraction}

Twenty grams of ground fruit were dissolved in $100 \mathrm{~mL}$ of hexane or acetone. The suspension was sonicated for $1 \mathrm{~h}$ and then filtered and concentrated to dryness. The residue was resuspended in $5 \mathrm{~mL}$ of the extraction solvent, and an aliquot of $0.5 \mu \mathrm{L}$ was injected in the GC/MS system under the same conditions used for volatiles with the following temperature differences: injector and detector were maintained at $300{ }^{\circ} \mathrm{C}$ and the oven was heated from $70^{\circ} \mathrm{C}$ to $280^{\circ} \mathrm{C}$ at $10^{\circ} \mathrm{C} / \mathrm{min}$. 


\section{Results and discussion}

\subsection{Bioactive compounds}

Table 1 shows the quantified bioactive compounds found in 'Tupy' blackberry grown in Southern Brazil, which includes phenolic compounds, carotenoids, tocopherols, and

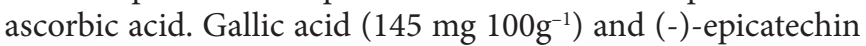
(94 mg $100 \mathrm{~g}^{-1}$ ) were the predominant phenolic compounds. Blackberry species Rubus glaucus and $R$. adenotrichus have been shown to contain the phenolic compounds gallic acid, (-)-epicatechin, ferulic, and caffeic acids, in addition to kaempferol, ellagic, and p-coumaric acid. 'Marion' (Rubus sp. hyb) and 'Evergreen' ( $R$. laciniatus) blackberries have ellagic acid, gallic acid, quercetin, and kaempferol (Mertz et al., 2007; Siriwoharn \& Wrolstad, 2004). In general, the qualitative and quantitative phenolic profile of 'Tupy' was similar to others of previously reported in studies on blackberry.

Table 1. Content of bioactive compounds in blackberry cv. Tupy.

\begin{tabular}{|c|c|}
\hline Compounds & $\begin{array}{c}\text { Concentration (mg } 100 \mathrm{~g}^{-1} \\
\text { f.w. } \pm \text { std deviation) }\end{array}$ \\
\hline hydroxybenzoic acid & $1.44 \pm 0.20$ \\
\hline gallic acid & $145.85 \pm 3.10$ \\
\hline quercetin & $20.62 \pm 0.90$ \\
\hline caffeic acid & $1.69 \pm 0.30$ \\
\hline ferulic acid & $22.09 \pm 1.20$ \\
\hline (-)-epicatechin & $94.29 \pm 4.10$ \\
\hline$\delta$-tocopherol & $0.49 \pm 0.03$ \\
\hline$(\beta+\gamma)$-tocopherol & $0.24 \pm 0.02$ \\
\hline$\alpha$-tocopherol & $0.12 \pm 0.01$ \\
\hline L-ascorbic acid & $0.90 \pm 0.02$ \\
\hline$\beta$-cryptoxanthin & $0.24 \pm 0.10$ \\
\hline lutein + zeaxanthin & $0.51 \pm 0.30$ \\
\hline$\beta$-carotene & $0.01 \pm 0.01$ \\
\hline lycopene & $0.02 \pm 0.01$ \\
\hline
\end{tabular}

'Tupy' had a small amount of the bioactive molecules tocopherols, carotenoids, and ascorbic acid (Table 1). The $\delta$ - and $\alpha$-tocopherol peaks were well resolved; however, $\beta$ - and $\gamma$-tocopherol did not separate under the chromatographic conditions used and were therefore quantified together. Ascorbic acid, an antioxidant molecule active in oxidative stress reactions, was found in low amounts in 'Tupy' (Table 1) when compared to those of previous reports, from 14.3 to $17.5 \mathrm{mg}$ $100 \mathrm{~g}^{-1} \mathrm{fw}$, which were found in other cultivars (Pantelidis et al., 2007). Carotenoids are among the most important pigments accumulated in fruits and may serve as precursors for VOCs. $\beta$-ionone and geranylacetone, for example, are produced from the degradation of $\beta$-carotene and lycopene, respectively (Stevens et al., 1979). Although both $\beta$-carotene and lycopene were found in this study, their concentrations were low (Table 1). The results found in the present study are in agreement with the hypothesis that antioxidant metabolites and defense compounds, such as the quantified bioactive molecules, compensate each other and are not all expressed at the same time.

\subsection{Volatile organic compounds}

Table 2 shows all 45 volatile compounds identified in the blackberry collected with SPME. The identified compounds represented approximately $77 \%$ of the total area of the chromatogram (Figure 1); the vast majority (97.7\%) was composed of terpenoids, and limonene was the predominant compound (Table 2). Identified volatiles extracted with hexane were primarily hydrocarbons (Table 3 ), and those extracted with acetone were furans and pyrans (Table 4). Approximately $60 \%$ of the total peak area of the chromatogram (Figure 2) of hexane-extracted volatiles were identified, and most of the compounds were aliphatic, while only $13 \%$ were aromatic. In the chromatogram of the acetone extract (Figure 3 ), the identified compounds represented $82 \%$ of the total peak area.

Aroma volatile compound formation is associated with pigment formation during ripening; ${ }^{3}$ however, some compounds

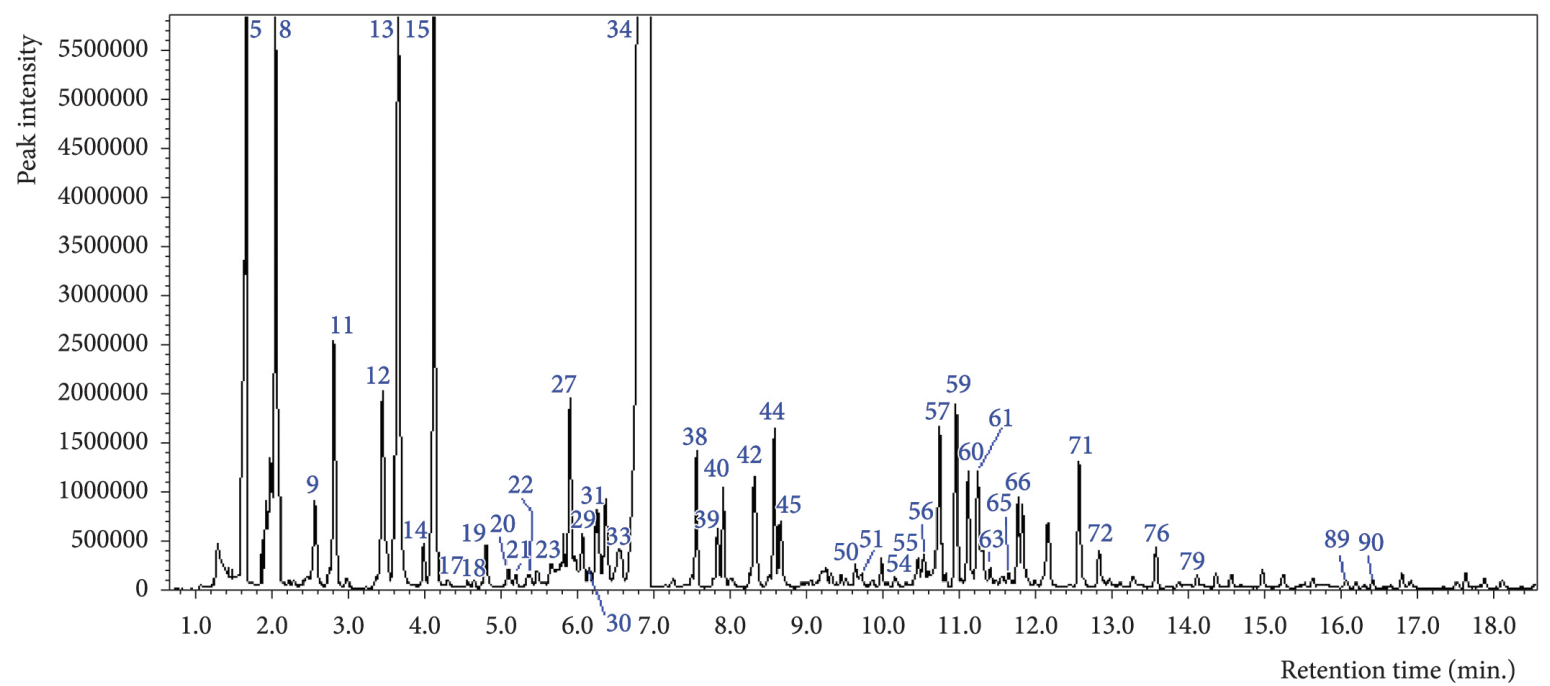

Figure 1. Total ion chromatogram of volatile compounds from blackberry cv. Tupy collected using SPME (chromatographic conditions described in the materials and methods section). 
Table 2. Volatile compounds identified in blackberry cv. Tupy.

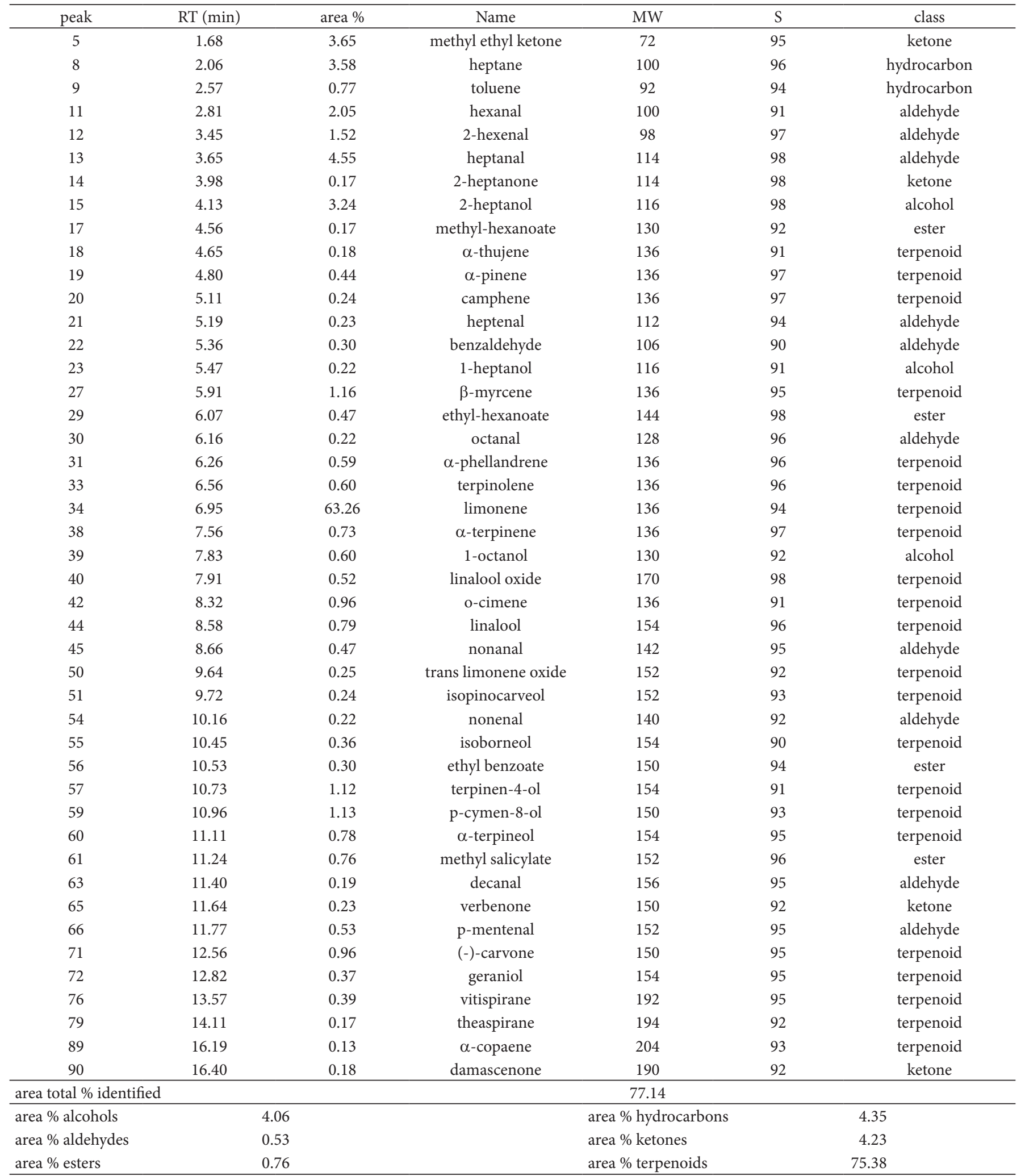

$\mathrm{MW}=$ molecular weight; $\mathrm{S}=$ similarity with mass spectra; $\%$ area $=$ area $\%$ related to the total peak area. 
such as hexanal and (E)-2-hexenal that can be generated from oxidation or lipoxygenase-catalyzed oxidative degradation of fatty acids (Sanz et al., 1997) typically decrease with fruit maturity. Volatile composition also varies both among and within cultivars, thus being genotype specific (Du et al., 2010).

The major chemical groups of VOCs responsible for the flavor of fruit berries are esters, alcohols, ketones, aldehydes, terpenoids, furanones, and sulfur compounds (Christensen et al., 2007). For industrial purposes, 'Black Diamond', a thornless blackberry cultivar with large fruit size and high yield, is considered ideal. 'Marion' is not as large or productive, but it is regarded as having the ideal flavor with predominance of furaneol, linalool, $\beta$-ionone, and hexanal (Du et al., 2010). The ideal volatiles found in 'Marion' were also found in 'Tupy'.

Furaneol, linalool, geraniol, ethyl hexanoate, trans-2hexenol, and $\beta$-ionone are responsible for fresh fruit, floral, strawberry, and raspberry aromas, while 1-octen-3-ol, myrtenol, eugenol, and $\alpha$-terpineol account for vegetal, woody, moldy, and cooked fruit flavors (Du et al., 2010). Heptanol and p-cymen8-ol have also been identified as the most important volatile component of blackberry flavor, and their contribution has been described as fruity-herbaceous and flowery-spicy, respectively (Ibáñez et al., 1998).

Table 3. Semivolatile compounds identified in blackberry cv. Tupy extracted with hexane.

\begin{tabular}{|c|c|c|c|c|c|}
\hline peak & $\mathrm{RT}(\min )$ & Name & Area $\%$ & MW & $\mathrm{S}$ \\
\hline 4 & 3.65 & aliphatic hydrocarbon & 3.97 & & \\
\hline 5 & 3.69 & aliphatic hydrocarbon & 1.99 & & \\
\hline 6 & 3.76 & aliphatic hydrocarbon & 1.31 & & \\
\hline 9 & 3.95 & aliphatic hydrocarbon & 0.98 & & \\
\hline 10 & 4.04 & aliphatic hydrocarbon & 5.06 & & \\
\hline 11 & 4.11 & C2-benzene & 1.63 & 106 & 93 \\
\hline 12 & 4.18 & aliphatic hydrocarbon & 1.71 & & \\
\hline 16 & 4.60 & $\mathrm{n}$ - decane & 8.91 & 142 & 93 \\
\hline 20 & 4.95 & aliphatic hydrocarbon & 2.44 & & \\
\hline 21 & 5.04 & C3-benzene & 2.67 & 120 & 92 \\
\hline 22 & 5.15 & aliphatic hydrocarbon & 1.64 & & \\
\hline 28 & 5.46 & C4-benzene & 1.27 & 134 & 92 \\
\hline 32 & 5.87 & aliphatic hydrocarbon & 1.50 & & \\
\hline 36 & 6.15 & $\mathrm{n}$ - undecane & 5.05 & 156 & 97 \\
\hline 52 & 7.57 & naphthalene & 0.66 & 128 & 94 \\
\hline 53 & 7.66 & $\mathrm{n}$-dodecane & 2.46 & 170 & 95 \\
\hline 55 & 7.86 & aliphatic hydrocarbon & 0.71 & & \\
\hline 64 & 9.09 & $\mathrm{n}$ - tridecane & 1.81 & 184 & 95 \\
\hline 65 & 9.16 & C1 naphthalene & 0.50 & 142 & 91 \\
\hline 66 & 9.44 & C1 naphthalene & 0.18 & 142 & 96 \\
\hline 72 & 10.33 & aliphatic hydrocarbon & 0.49 & & \\
\hline 73 & 10.78 & $\mathrm{n}$ - tetradecane & 1.55 & 198 & 96 \\
\hline 74 & 11.08 & C2 naphthalene & 0.23 & 156 & 95 \\
\hline 75 & 11.41 & C2 naphthalene & 0.23 & 156 & 95 \\
\hline 76 & 11.49 & C2 naphthalene & 0.29 & 156 & 94 \\
\hline 78 & 12.17 & aliphatic hydrocarbon & 0.87 & & \\
\hline 80 & 13.24 & $\mathrm{n}$ - pentadecane & 1.81 & 212 & 98 \\
\hline 81 & 14.47 & C3 naphthalene & 0.17 & 170 & 94 \\
\hline 83 & 17.07 & $\mathrm{n}$ - hexadecane & 1.90 & 226 & 97 \\
\hline 85 & 21.46 & $\mathrm{n}$ - heptadecane & 1.84 & 240 & 97 \\
\hline 86 & 21.61 & pristine & 1.29 & 268 & 93 \\
\hline 88 & 23.73 & $\mathrm{n}$ - octadecane & 1.29 & 254 & 97 \\
\hline 89 & 23.89 & phytane & 0.49 & 282 & 93 \\
\hline 91 & 25.34 & $\mathrm{n}$ - nonadecane & 0.91 & 282 & 95 \\
\hline 92 & 26.64 & $\mathrm{n}$ - eicosane & 0.50 & 296 & 95 \\
\hline 93 & 27.76 & $\mathrm{n}$ - heneicosane & 0.26 & 310 & 95 \\
\hline \multicolumn{4}{|c|}{$\%$ area identified compounds } & \multicolumn{2}{|c|}{60.54} \\
\hline$\%$ aliphatic & & & & \multicolumn{2}{|c|}{52.72} \\
\hline$\%$ aromatic & & & & \multicolumn{2}{|c|}{7.84} \\
\hline
\end{tabular}

$\mathrm{MW}=$ molecular weight; $\mathrm{S}=$ similarity with mass spectra; $\%$ area $=$ area $\%$ related to the total peak area. 
Table 4. Semivolatile compounds identified in blackberry cv. Tupy extracted with acetone.

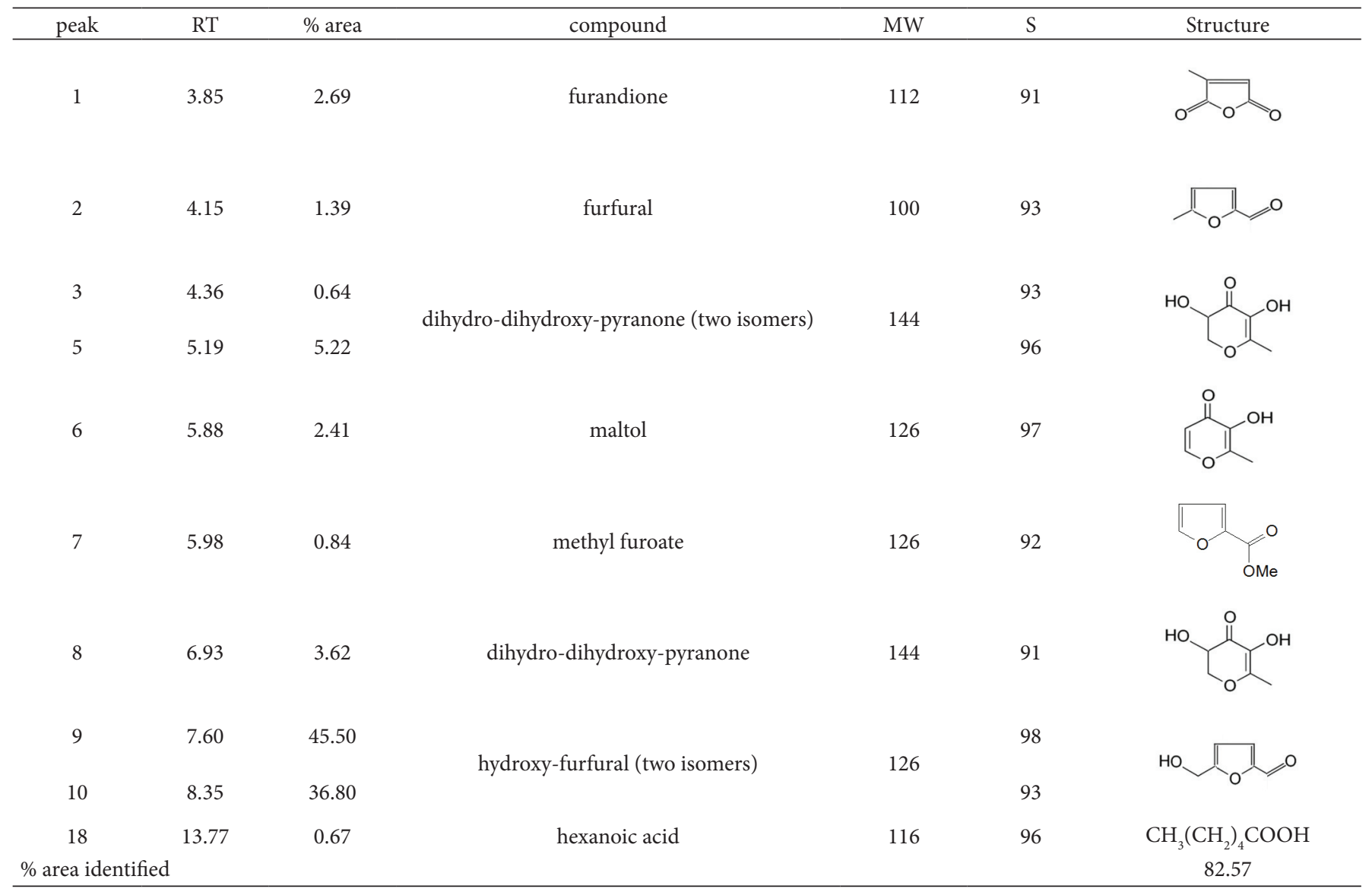

MW = molecular weight; $\mathrm{S}=$ similarity with mass spectra; $\%$ area $=$ area $\%$ related to the total area of identified peak.

The following compounds found in 'Tupy' had been previously found in other Rubus spp.: 2-heptanol, 1-hexanol, 1-octanol, hexanal, nonanal, 2-decenal, 2-heptanone, and methyl salicylate in Andean blackberry ( . glaucus); 2-butanone, hexenal, and nonanal in arctic bramble ( $R$. articus) (Meret et al., 2011); 1-hexanol, 2-heptanol, 1-octanol, p-cymen-8-ol, 2 -heptanone, $\alpha$-terpineol, pulegone, isoborneol, myrtenol, 4-terpineol, carvone, elemicine, nonanal, benzyl alcohol, benzoic acid, and 3-hydroxy-7,8-dihydro- $\beta$-ionol, in $R$. laciniata (Georgilopoulos \& Gallois, 1987); acetic and hexanoic acids, trans 3-penten-1-ol, 2-heptanol, 3-methyl-2-buten-1-ol, benzyl alcohol, and linalool in hybrids between $R$. idaeus and $R$. arcticus; and $\beta$-ionone, 2-heptanone, geraniol, limonene, linalol, $\alpha$-pinene and 4-terpineol in R. idaeus (Machado et al., 2007; Malowicki et al., 2008).

Blackberry fruit processed as juice alone or in combination with other fruit had furfural, 3-methyl-butanal, 3-methyl1-butanol, phenylacetaldehyde, trans-furan linalool oxide, 6-methyl-5-hepten-2-one, $\alpha$-terpineol, and $E$-nerol as the main volatile aroma compounds (Georgilopoulos \& Gallois, 1987;
Vazquez-Araujo et al., 2010), indicating that these compounds found in 'Tupy' may be associated with an advanced ripening stage.

Moreover, some of the identified volatile compounds have been associated with plant pathogen control. Hexanal, 1-hexanol, (E)-2-hexen-1-ol, (Z)-6-nonenal, (E)-3-nonen-2one, methyl salicylate, and methyl benzoate exhibited potential as postharvest fumigants for control of Botrytis on strawberry (Archbold et al., 1997).

\section{Conclusion}

The main flavor active compounds previously reported in Rubus spp. are also present in the Southern Brazilian blackberry 'Tupy'. 'Tupy' is a high quality blackberry with the potential to be used in an array of new products based on its bioactive and aroma volatile profile. Further studies investigating optimization of production, postharvest conservation, and processing with the goal of quality improvement and grower and consumer benefits are needed to support the wide utilization of this cultivar. 

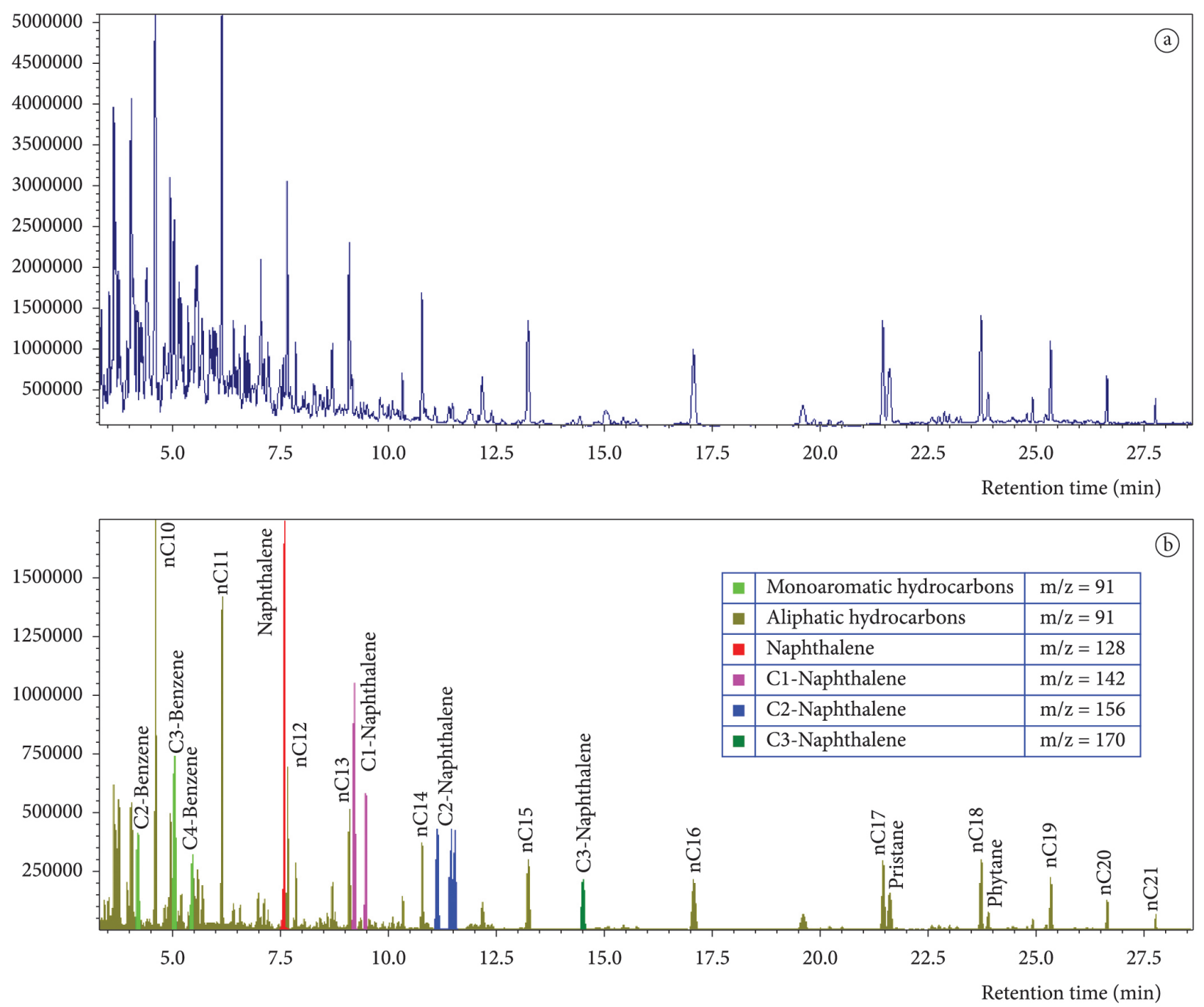

Figure 2. (a)Total ion chromatogram and (b) Monitored ion chromatogram of blackberry cv. Tupy volatiles extracted with hexane (chromatographic conditions described in the materials and methods section).

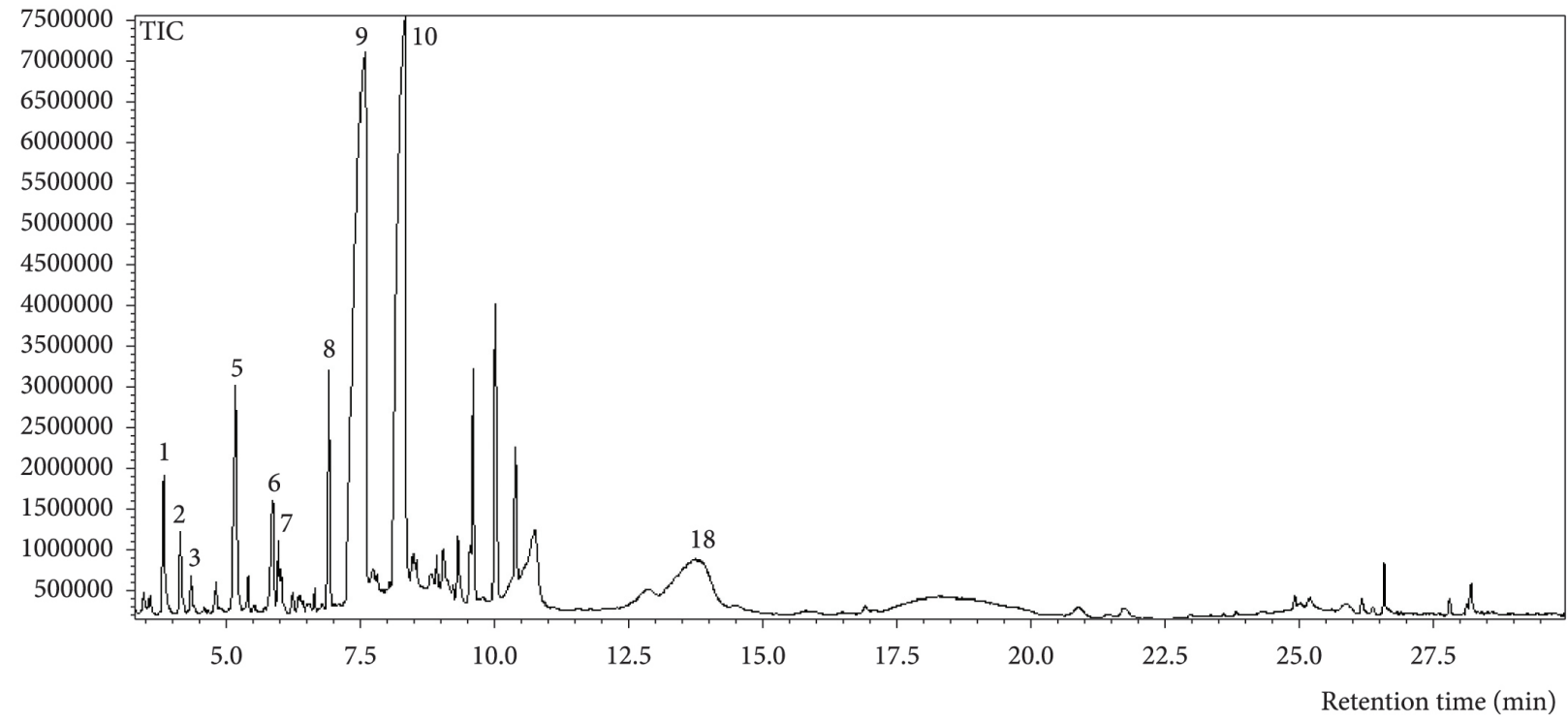

Figure 3. Total ion chromatogram of blackberry cv. Tupy volatiles extracted with acetone (chromatographic conditions described in the materials and methods section). 


\section{Acknowledgements}

The authors are grateful to the Federal University of Rio Grande do Sul - UFRGS for the volatile organic compound analysis.

\section{References}

Antunes, L. E. C. (2002). Blackberry: a new crop option to Brazil. Ciência Rural, 32(1), 151-158. http://dx.doi.org/10.1590/S010384782002000100026

Archbold, D. D., Hamilton-Kemp, T. R., Barth, M. M., \& Langlois, B. E. (1997). Identifying natural volatile compounds that control gray mold (Botrytis cinerea) during postharvest storage of strawberry, blackberry, and grape. Journal of Agricultural and Food Chemistry, 45(10), 4032-4037. http://dx.doi.org/10.1021/jf970332w

Ayhan, Z., Yeom, H. W., Zhang, Q. H., \& Min, D. B. (2001). Flavor, color, and vitamin $\mathrm{C}$ retention of pulsed electric field processed orange juice in different packaging materials. Journal of Agricultural and Food Chemistry, 49(2), 669-674. PMid:11262010. http://dx.doi. org/10.1021/jf000984b

Christensen, L. P., Edelenbos, M., \& Kreutzmann, S. (2007). Fruits and vegetables of moderate climate. In R. G. Berger (Ed.), Flavours and fragrances: chemistry, bioprocessing and sustainability (pp. 135-187). Berlin: Springer.

Du, X., Finn, C. E., \& Qian, M. C. (2010). Bound volatile precursors in genotypes in the pedigree of 'Marion' blackberry (Rubus sp.). Journal of Agricultural and Food Chemistry, 58(6), 3694-3699. PMid:20192206. http://dx.doi.org/10.1021/jf9034089

Finn, C. E. (2008). Blackberries. In J. F. Hancock (Ed.), Temperate fruit crop breeding: germplasm to genomics (pp. 83-114). Netherlands: Springer. http://dx.doi.org/10.1007/978-1-4020-6907-9_3

Georgilopoulos, D. N., \& Gallois, A. N. (1987). Aroma compounds of fresh blackberries (Rubus laciniata L.). Zeitschrift für LebensmittelUntersuchung und Forschung, 184(5), 374-380. http://dx.doi. org/10.1007/BF01126660

Hakkinen, S. H., Karenlampi, S. O., Heinonen, I. M., Mykkanen, H. M., \& Torronen, A. R. (1998). HPLC method for screening of flavonoids and phenolic acids in berries. Journal of the Science of Food and Agriculture, 77(4), 543-551. http://dx.doi.org/10.1002/(SICI)10970010(199808)77:4<543::AID-JSFA78>3.0.CO;2-I

Ibáñez, E., López-Sebastián, S., Ramos, E., Javier, T., \& Reglero, G. (1998). Analysis of volatile fruit components by headspace solidphase microextraction. Food Chemistry, 63(2), 281-286. http:// dx.doi.org/10.1016/S0308-8146(98)00001-6

Kallio, H., \& Linko, R. R. (1973). Volatile monocarbonyl compounds of arctic bramble (Rubus arcticus) at various stages of ripeness. Zeitschrift für Lebensmittel-Untersuchung und Forschung, 153(1), 23-30. http://dx.doi.org/10.1007/BF01267715

Klesk, K., \& Qian, M. (2003). Preliminary aroma comparison of Marion (Rubus spp. hyb) and Evergreen (R. laciniatus L.) blackberries by dynamic headspace/OSME technique. Journal of Food Science, 68(2), 697-700. http://dx.doi.org/10.1111/j.1365-2621.2003.tb05734.x

Machado, C. C. B., Bastos, D. H. M., Janzantti, N. S., Facanali, R., Marques, O. M., \& Franco, M. R. B. (2007). Volatile compounds profile and flavor analysis of yerba mate (Ilex paraguariensis) beverages. Química Nova, 30(3), 513-518. http://dx.doi.org/10.1590/ S0100-40422007000300002

Malowicki, S. M. M., Martin, R., \& Qian, M. C. (2008). Comparison of sugar, acids, and volatile composition in raspberry bushy dwarf virus-resistant transgenic raspberries and the wild type 'Meeker' (Rubus idaeus L.). Journal of Agricultural and Food Chemistry, 56(15), 6648-6655. PMid:18598047. http://dx.doi.org/10.1021/ jf800253e

Meret, M., Brat, P., Mertz, C., Lebrun, M., \& Gunata, Z. (2011). Contribution to aroma potential of Andean blackberry (Rubus glaucus Benth.). Food Research International, 44(1), 54-60. http:// dx.doi.org/10.1016/j.foodres.2010.11.016

Mertz, C., Cheynier, V., Gunata, Z., \& Brat, P. (2007). Analysis of phenolic compounds in two blackberry species (Rubus glaucus and Rubus adenotrichus) by high-performance liquid chromatography with diode array detection and electrospray ion trap mass spectrometry. Journal of Agricultural and Food Chemistry, 55(21), 8616-8624. PMid:17896814. http://dx.doi.org/10.1021/jf071475d

Pantelidis, G. E., Vasilakakis, M., Manganaris, G. A., \& Diamantidis, Gr. (2007). Antioxidant capacity, phenol, anthocyanin and ascorbic acid contents in raspberries, blackberries, red currants, gooseberries and Cornelian cherries. Food Chemistry, 102(3), 777-783. http:// dx.doi.org/10.1016/j.foodchem.2006.06.021

Pyysalo, T. (1976). Identification of volatile compounds in hybrids between raspberry (Rubus idaeus, L.) and arctic bramble (Rubus arcticus, L.). Zeitschrift für Lebensmittel-Untersuchung und Forschung, 162(3), 263-272. PMid:1007619. http://dx.doi. org/10.1007/BF01113308

Riu-Aumatell, M., Castellari, M., López-Tamames, E., Galassi, S., \& Buxaderas, S. (2004). Characterization of volatile compounds of fruit juices and nectars by HS/SPME and GC/MS. Food Chemistry, 87(4), 627-637. http://dx.doi.org/10.1016/j.foodchem.2003.12.033

Rodrigues-Amaya, D. B. (2001). A guide to carotenoid analysis in foods. Washington: ILST Press. $64 \mathrm{p}$.

Sanz, C., Olías, J. M., \& Perez, A. G. (1997). Aroma biochemistry of fruits and vegetables. In F. A. Tomas-Barberán \& R. J. Robins (Eds.), Phytochemistry of fruit and vegetables (pp. 125-155). Oxford: Clarendon Press.

Seeram, N. P., Adams, L. S., Zhang, Y., Lee, R., Sand, D., Scheuller, H. S., \& Heber, D. (2006). Blackberry, black raspberry, blueberry, cranberry, red raspberry, and strawberry extracts inhibit growth and stimulate apoptosis of human cancer cells in vitro. Journal of Agricultural and Food Chemistry, 54(25), 9329-9339. PMid:17147415. http://dx.doi.org/10.1021/jf061750g

Siriwoharn, T., \& Wrolstad, R. E. (2004) Polyphenolic composition of Marion and Evergreen blackberries. Journal of Food Science, 69(4), 233-240.

Stevens, M. A., Kader, A. A., \& Albright, M. (1979). Potential for increasing tomato flavor via increased sugar and acid content. Journal of the American Society for Horticultural Science, 104(1), 40-42.

Vazquez-Araujo, L., Chambers, E. IV, Adhikari, K., \& CarbonellBarrachina, A. A. (2010). Sensory and physicochemical characterization of juices made with pomegranate and blueberries, blackberries, or raspberries. Journal of Food Science, 75(7), S398-S404. PMid:21535574. http://dx.doi.org/10.1111/j.17503841.2010.01779.x 
